\title{
Marketing Strategy of Traditional Cake of Mandar (Kue Kasippi) at CV Devadata 59 Polewali Mandar
}

\author{
Lina mariana ${ }^{1}, \mathrm{M}$. Dakhri $\mathrm{S}^{2}$, etc \\ \{linamariana5390@gmail.com¹,mdakhri@gmail.com² \\ Politeknik LP3I Makassar, j1. Sultan Alauddin No 250 Makassar $^{1,2}$
}

\begin{abstract}
The aims to determine what marketing strategy is most appropriate to be applied to a food product called kasippi cake. The type of research used is descriptive qualitative which described the results of observations and interviewed through field studies with Owner CV Devadata 59. This research conducted from February to May 2021. The results showed that the marketing strategy in increasing profit turnover at CV Devadata 59. 1. online marketing strategy through social media, 2. direct marketing strategy, namely through promotion through collaboration with regional passenger drivers.
\end{abstract}

Keywords: Marketing; Strategy of Product

\section{Introduction}

Companies and business entities in carrying out their activities, both those engaged in the business of services, goods, and culinary, have the same goal in general, namely to earn profits. In addition, the company also wants to provide satisfaction to consumers for the products it produces, because customer satisfaction is a measure of the company's success in producing quality products, and what consumers want. Product is anything that is offered to the market for attention, acquisition and use or consumption to satisfy needs and wants in the form of physical, service, people, organization and idea [1]. Therefore, companies need the right marketing process so that what the company wants can be achieved and customers entrust their needs to us. Until now, marketing greatly affects the success of a company to survive in market share. Therefore, a marketing strategy is needed that can give influence to determine whether or not it is successful in marketing its products.

Marketing strategy is generally marketing logic, and based on it, the business unit is expected to achieve its marketing objectives. And consists of making decisions about the company's marketing costs, marketing mix, and marketing allocation. Can be stated as the basis of action that leads to marketing activities or efforts, of a company, in conditions of competition and an ever-changing environment in order to achieve the expected goals. Marketing strategy is indeed a supporter of the success of a company in market share. Marketing strategy is an effort to market a product, be it goods or services, using certain patterns of plans and tactics so that the number of sales is higher. And can also be interpreted as a series of efforts made by the company in order to achieve certain goals, because the potential to sell the proposition is limited to the number of people who know about it [2]. 
According to the quoted Philip Kotler [2], the definition of marketing strategy is a marketing mindset that will be used to achieve marketing goals, in which there is a detailed strategy regarding the target market, positioning, marketing mix, and budget for marketing. According to Kurtz, marketing strategy is the entire program of the company in determining the target market and satisfying consumers by building a combination of elements of the marketing mix; product, distribution, promotion, and price [2]. Kasippi cake is a traditional food originating from the Mandar area, precisely in the Polewali Mandar district, South Sulawesi province. Kasippi cake is an ancestral heritage which is said to have existed since the Dutch era, the secret of the taste and characteristic of the kasippi cake lies in the ingredients used in its presentation. Kasippi cake is made from wheat flour, eggs, and vanilla as a flavoring, granulated sugar, brown sugar and water or coconut milk is added to thicken the dough. The increase in profit in CV DEVADATA 59 is still very minimal and inversely proportional to the taste of the product it produces. Therefore, another alternative to be taken is to create a suitable marketing strategy for the product.

\section{Methodology}

This research is a type of qualitative research with qualitative descriptive data analysis methods. Qualitative research is a research procedure that produces descriptive data in the form of written or spoken words from people and observable behavior. This approach is directed at the individual as a whole. So in terms of not isolating individuals or organizations [3]. The research was carried out from February 2021 to May 2021. The focus of the research was only on marketing strategies for traditional Mandar cuisine and what needs to be considered in setting these strategies.

\section{Results and Discussion}

Research results can be described as follows:

a) The role of marketing strategy. Based on the results of interviews with key informants (owners) of CV Devadata 59 polewali mandar it is said that: "So far we are very aware that the role of marketing strategy in our business is very important. Because without a marketing strategy, it will be difficult to introduce the product to the public. Considering that in the future, basic human needs can be obtained easily. As with the online market and so on. One of the limitations we encountered in this business was the limited space for displaying products to make it easier for the market to reach". ( interview, 20 April 2021)

b) How to Increase the Company Profit. Based on the results of the interview it was found that:"The company only relies on profits to direct sales processes. Currently, our business only has one place to sell our products and at the same time it is also a place of production for our products." (interview, 20 April 2021)

c) Supporting and inhibiting factors. The supporting factors are computer media, cellphones, internet, to facilitate the sales process or product introduction to the public. While the actual inhibiting factors are related to obstacles as long as humans live, there will always be obstacles, and when talking about obstacles, we will always try to minimize obstacles so that these obstacles do not interfere with the running of the company and do not become a weakness for us, even if we need to make obstacles opportunity as strength. 
d) Barriers in the marketing process. Based on the results of the interview: "The obstacle we are currently facing is that we do not have a new branch to introduce products. Because most of our customers come from outside the region, so we need a new place (new branch) in an area where there are many of our customers. (interview, 20 April 2021).

\section{Results and Discussion}

Based on the results of research and discussion from the previous chapter, the authors can conclude that in a company marketing strategy certainly has a very important role, as well as in CV Devadata 59 Polewali Mandar, strategy acts as a driver in order to facilitate company profits so that the company is able to survive the process. Production besides the most common roles such as marketing as a channel to introduce the product more broadly. The importance of marketing strategy. Marketing has an important role to help companies because with marketing, a company can more easily introduce its products and help achieve the desired goals in accordance with the existing rules within the company. One of the marketing strategies used is an online marketing strategy (through social media). This strategy is used to introduce Kasippi Cake products to a wider market.

In addition to online marketing strategies, CV Devadata 59 also uses a promotional strategy, namely by collaborating with regional passenger drivers by providing free cakes for regional passenger drivers. So that every regional passenger driver who passes by, must stop by the shop to pick up free cakes that also carry passengers. Indirectly, when the driver stops, there will also be passengers who get off to buy Kasippi cakes. The product of Kus Kasippi CV Devadata 59 also offers affordable prices for all levels of society because the products are in bandroll starting from Rp. 5,000 to IDR 50,000 per package. Promotion is an activity and material in its application using techniques, under the control of the seller/manufacturer, that can communicate interesting persuasive information about the products offered by the seller/manufacturer, either directly or through parties that can influence the purchase [4].

\section{Conclusion}

Based on the results of research and discussion in the previous chapter, it is concluded that the marketing strategy used is online marketing strategy and direct marketing strategy.

\section{References}

[1] H. Malau, Manajemen Pemasaran, Jakarta: Alfabeta, 2016.

[2] W. Wardana, Strategi Pemasaran, Jakarta: Alfabeta, 2017.

[3] D. Sugiyono, Metode Penelitian, Jakarta: Alfabeta, 2016.

[4] D. Sunyoto, Dasar-Dasar Manajemen Pemasaran, Jakarta: CAPS (Center Of Academic Publishing Service), 2016. 